\title{
Selection of plum genotypes for resistance to leaf scald
}

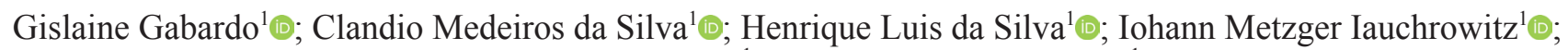 \\ Flávio Corrêa Carvalho ${ }^{1}\left[\right.$, Rui Pereira Leite Junior ${ }^{1}[0$
}

${ }^{1}$ IAPAR - Instituto Agronômico do Paraná - Av. Presidente Kennedy, s/nº , 84001-970 Ponta Grossa-PR, Brazil.

Corresponding Author: Gislaine Gabardo (gislainegabardo2007@yahoo.com.br)

Data de chegada: 30/05/2020. Aceito para publicação em: 20/08/2020.

$10.1590 / 0100-5405 / 238868$

\section{ABSTRACT}

Gabardo, G.; Silva, C.M.; Silva, H.L.; Iauchrowitz, I.M.; Carvalho, F.C.; Leite Junior, R.P. Selection of plum genotypes for resistance to leaf scald. Summa Phytopathologica, v.46, n.4, p.305-307, 2020.

Plum (Prunus salicina Lindl.) cultivation is seriously compromised in Brazil due to the occurrence of leaf scald, a disease caused by the bacterium Xylella fastidiosa subsp. multiplex. The objective of this study was to evaluate plum genotypes agronomically promising for resistance to leaf scald, under natural conditions of occurrence of the disease. Ten out of 50 plum genotypes belonging to the germplasm bank of "Instituto Agronômico do Paraná (IAPAR)" were selected. Five evaluations of leaf scald severity were carried out from January to February (2017 and 2018). Polymerase chain reaction (PCR) was also performed for samples of these genotypes to determine the presence of the bacterium $X$. fastidiosa subsp. multiplex. The genotypes differed in relation to their susceptibility to leaf scald. PR-1095 was the most resistant genotype and did not show any leaf symptom of the disease. In contrast, genotypes PR-1126 and PR-1137 had the greatest susceptibility to the disease, showing severe scald symptoms. However, PCR revealed the presence of the bacterium even in the most resistant genotypes, indicating, for example, that PR-1095, which had no symptoms of the disease, is probably tolerant to leaf scald.

Keywords: Prunus salicina Lindl., Xylella fastidiosa subsp. multiplex, new cultivars.

\section{RESUMO}

Gabardo, G.; Silva, C.M.; Silva, H.L.; Iauchrowitz, I.M.; Carvalho, F.C.; Leite Junior, R.P. Seleção de genótipos de ameixa para resistência à escaldadura das folhas. Summa Phytopathologica, v.46, n.4, p.305-307, 2020.

O cultivo da ameixa (Prunus salicina Lindl.) Está seriamente comprometido no Brasil pela ocorrência de queima de folhas, uma doença causada pela bactéria Xylella fastidiosa subsp. multiplex. O objetivo do estudo foi avaliar genótipos de ameixa agronomicamente promissores em relação à resistência à escaldadura, sob condições naturais de ocorrência da doença. Dez genótipos de ameixa foram selecionados entre os 50 pertencentes ao banco de germoplasma do Instituto Agronômico do Paraná (IAPAR). Foram realizadas cinco avaliações da severidade da escaldadura das folhas, de janeiro a fevereiro (2017 e 2018). O teste de reação em cadeia da polimerase
(PCR) também foi realizado em amostras desses genótipos para determinar a presença da bactéria $X$. fastidiosa subsp. multiplex. Os genótipos diferiram em relação à suscetibilidade à queima de folhas. O genótipo PR-1095 foi o mais resistente e não apresentou nenhum sintoma foliar da doença. Por outro lado, os genótipos PR-1126 e PR-1137 tiveram a maior suscetibilidade à doença, com graves sintomas de queimadura. No entanto, o teste de PCR revelou a presença da bactéria mesmo nos genótipos mais resistentes, indicando, por exemplo, que o genótipo PR-1095, sem sintomas da doença, provavelmente é tolerante à queima das folhas.

Palavras-chave: Prunus salicina Lindl., Xylella fastidiosa subsp. multiplex, novas cultivares.

Plum (Prunus salicina Lindl.) cultivation has significant economic importance in Brazil, especially in the southern states, which have favorable climate conditions to produce this fruit tree. Rio Grande do Sul has several areas suitable for growing plum and is the major Brazilian state producing this fruit (6).

However, Brazilian plum production has shown great losses in productivity and a reduction in the cultivated area, especially due to leaf scald, caused by the bacterium $X$. fastidiosa subsp. multiplex. This disease that drastically affects the productivity and the longevity of plum plants is widespread among the main producing regions of Brazil $(1,15,18)$.

$X$. fastidiosa subsp. multiplex is transmitted by several xylemsucking sharpshooters (Hemiptera: Cicadellidae, Cicadellinae). This bacterium is limited to the xylem and obstructs these vessels, blocking the plant's vascular system, which is responsible for translocating water and nutrients. The first symptom of scald is leaf tip burn, followed by dry branches, culminating in the death of the plant $(5,10,12)$.

Although plum cultivation has great economic importance and has suffered considerable damage due to this disease, few studies have been carried out on leaf scald of plums in Brazil and worldwide, making it difficult to learn and understand this pathology. Most information available about diseases caused by $X$. fastidiosa originated from research conducted with citrus, grapevine, coffee and olive $(2,8,11)$.

Due to the difficulties in preventing and managing leaf scald, the major control measure consists in developing resistant plum cultivars. Thus, the use of resistant cultivars becomes the best control method since there are no curative measures for this disease; besides, the control of insect vectors has technical limitations and is not economically viable for most producers $(12,15,17)$.

Plum cultivars that are highly resistant to the disease do not have satisfactory agronomic qualities for commercial production. In contrast, plum cultivars showing better agronomic traits, such as 'Irati', 
'Polirosa' and 'Santa Rosa', show high susceptibility to leaf scald (7). Thus, the need for cultivars of high agronomic value and resistant to the disease has guided several breeding programs for plum in Brazil.

The main objectives of these programs are to obtain cultivars that are resistant to scald and that produce high yield and fruit quality. Consequently, the first step is to identify resistance sources that could be included in these breeding programs for the development of cultivars resistant to leaf scald. The objective of the present study was to evaluate plum genotypes agronomically promising for resistance to leaf scald under natural conditions of occurrence of the disease.

\section{MATERIAL AND METHODS}

The present study evaluated ten genotypes from the plum germplasm bank of "Instituto Agronômico do Paraná (IAPAR)", which were maintained under field conditions at the Ponta Grossa Regional Research Pole of IAPAR, Ponta Grossa, Paraná State, Brazil. These ten genotypes were selected from other 50 that belong to the germplasm bank based on desirable agronomic characteristics such as productivity and fruit quality. The main sources of resistance to leaf scald used in the breeding program were 'Chatard' and 'Piamontesa'. These plum cultivars are highly resistant to the disease but do not have satisfactory agronomic characteristics for commercial cultivation in Brazil.

The adopted experimental design was completely randomized, with 10 treatments, comprising the analyzed plum genotypes, and from 4 to 10 plants per genotype. Five evaluations of leaf scald severity were carried out from January to February 2017 and 2018. The evaluation was based on a scale of grades from 0 to 5 , where: $0=$ leaves without symptoms; 1 = leaves with symptoms in few branches; 2 = leaves with symptoms in approximately $50 \%$ branches; $3=$ leaves with symptoms in all branches; $4=$ dry branches in less than $50 \%$ of the plant; $5=$ dry branches in more than $50 \%$ of the plant. The obtained data were employed to calculate the disease severity index (SEV) for each genotype according to McKinney (13), using the equation: SEV $=[\Sigma$ (severity score $\mathrm{x}$ frequency) / (total number of units $\mathrm{x}$ severity) maximum)] x 100. After obtaining SEV for each genotype, statistical analysis was performed and means were grouped according to ScottKnott test $(\mathrm{P} \leq 0.05)$.

Branch samples of the plum genotypes were also evaluated for the presence of the leaf scald bacterium, $X$. fastidiosa subsp. multiplex. The branches were harvested in March (2017 and 2018). Five branches were collected from each plant of each genotype and stored in labeled plastic bags containing a portion of moistened cotton to avoid dehydration. Bags were stored in a polystyrene box and immediately sent to the laboratory. The presence of the bacterium was determined according to the conventional polymerase chain reaction (PCR) technique, using primers specific for $X$. fastidiosa subsp. multiplex $(14,19)$.

\section{RESULTS AND DISCUSSION}

The plum genotypes showed significant differences in relation to the severity of leaf scald (Table 1). Genotypes PR-1126 and PR-1137 had the greatest susceptibility to the disease. In contrast, PR-1020 and PR-1095 were least susceptible, while PR-1095 did not show any symptom of leaf scald in the two years. However, PCR revealed the presence of $X$. fastidiosa subsp. multiplex in samples from all plum genotypes, except PR-1013 in 2017 (Table 1).
Table 1. Severity of leaf scald in different plum genotypes and PCR test result for the presence of the bacterium Xylella fastidiosa subsp. multiplex. Ponta Grossa, 2017 and 2018.

\begin{tabular}{llccc}
\hline \multirow{2}{*}{ Genotype } & \multicolumn{2}{c}{ Severity $^{\mathrm{a}}$} & \multicolumn{2}{c}{ PCR Result $^{\mathrm{b}}$} \\
& $\mathbf{2 0 1 7}$ & $\mathbf{2 0 1 8}$ & $\mathbf{2 0 1 7}$ & $\mathbf{2 0 1 8}$ \\
\hline PR-1020 & $0.03 \mathrm{f}$ & $0.25 \mathrm{~g}$ & $5 / 6$ & $5 / 6$ \\
PR-1013 & $0.10 \mathrm{e}$ & $0.61 \mathrm{~d}$ & $0 / 5$ & $1 / 5$ \\
PR-1027 & $0.71 \mathrm{c}$ & $0.93 \mathrm{~b}$ & $5 / 6$ & $6 / 6$ \\
BY- 81-5850 & $0.29 \mathrm{~d}$ & $0.43 \mathrm{e}$ & $8 / 10$ & $8 / 10$ \\
FLA 86/2 & $0.06 \mathrm{e}$ & $0.20 \mathrm{~g}$ & $5 / 6$ & $5 / 6$ \\
PR-1095 & $0.00 \mathrm{f}$ & $0.00 \mathrm{~h}$ & $3 / 4$ & $2 / 4$ \\
PR-1162 & $0.32 \mathrm{~d}$ & $0.32 \mathrm{f}$ & $3 / 5$ & $3 / 5$ \\
PR-1126 & $0.86 \mathrm{a}$ & $0.99 \mathrm{a}$ & $4 / 4$ & $4 / 4$ \\
PR-1238 & $0.79 \mathrm{~b}$ & $0.84 \mathrm{c}$ & $4 / 4$ & $4 / 4$ \\
PR-1137 & $0.80 \mathrm{~b}$ & $1.00 \mathrm{a}$ & $2 / 2$ & $2 / 2$ \\
\hline CV (\%) & 11.33 & 9.94 & & \\
\hline
\end{tabular}

${ }^{a}$ Means followed by the same letter in the column do not differ according to Scott-Knott test at $5 \%$ probability, $\mathrm{CV}=$ coefficient of variation. ${ }^{\mathrm{b}}$ Number of positive samples / total number of tested samples.

The presence of the bacterium in genotypes that showed low disease severity, such as PR-1020, FLA 86/2 and PR-1095, indicates that these genotypes are tolerant to leaf scald, allowing bacterial multiplication in the plant tissues but not manifesting severe symptoms of the disease. On the other hand, according to the PCR test in 2017, PR-1013 proved to be resistant to leaf scald since it presented low disease severity and no detectable levels of the bacterium; however, in 2018, the disease was detected in one of the five evaluated plants (Table 1).

Transmission probably occurred due to the presence of sharpshooters (Hemiptera: Cicadellidae, Cicadellinae), which feed on the xylem of contaminated plants (16), in the same area. The disease is present in the evaluated orchard, besides being widely disseminated in the main producing regions of Brazil. Insects act on the local spread of leaf scald, while other forms of propagation (contaminated seedlings) contribute to the spread over long distances (15).

The disease severity progressed from 2017 to 2018 (Table 1), except for the genotypes PR-1095 and PR-1162; for PR-1095, there was no symptom of the disease, while PR-1162 showed the same severity in the two years of evaluation. Both genotypes had the bacterium detected by the molecular test.

The obtained results indicated that some of the plum genotypes, such as PR-1020 and PR-1095, are tolerant to the leaf scald pathogen. Thus, these genotypes can be recommended even for regions to which the bacterium $X$. fastidiosa subsp. multiplex is endemic. However, some care for disease management should be taken to ensure the productivity and longevity of plum plants (3).

In view of the difficulty in controlling this disease, the choice of the cultivar becomes an important factor to be considered. The use of resistant cultivars, if available, is the method that least affects the production cost. $X$. fastidiosa subsp. multiplex could make the economic exploitation of plum in Brazil impossible since it has been the main factor leading to the crop decline in southern and southeastern states of the country (12), in addition to causing early abandonment of orchards. 
Breeding programs have been developed to search for alternative sources of resistance (9). In 2017, EPAGRI launched 'Zafira', the first plum cultivar for commercial purposes that is not naturally infected with $X$. fastidiosa. However, bacterial transmission was noted to occur by grafting in this new cultivar. Apparently, there is a mechanism that blocks transmission by insect vectors (leafhoppers) because of nonpreference (3). The great advantage is the possibility of growing plums without incidence of leaf scald, but it is necessary to avoid any type of over-grafting with susceptible materials, which allows the bacterium to enter through the connection of xylem vessels (4).

Differently from the cultivar 'Zafira', the genotypes PR-1020 and PR-1095 had the bacterium detected by the molecular test (PCR) but showed low disease severity in the field (Table 1), indicating that the resistance mechanism of these genotypes is different from that of 'Zafira', which does not present the bacterium but may be contaminated by grafting and manifest the disease. PR-1020 and PR-1095 can live with the disease; however, further studies of these plum genotypes are necessary for them to be launched as new cultivars.

The evaluated plum genotypes differ in susceptibility to leaf scald. PR-1126 and PR-1137 were most susceptible to the disease, while PR1020 and PR-1095 were the most tolerant genotypes.

\section{REFERENCES}

1.Castro, L.A.S. Protocolo para diagnóstico de escaldadura das folhas da ameixeira. Pelotas: Embrapa Clima Temperado, 2010. 22p. (Embrapa Clima Temperado. Documentos, 324).

2. Coletta-Filho, H.; Francisco, C.S.; Lopes, J.R.S.; De Oliveira, A.F.Y.; Da Silva, L.F.O. First report of olive leaf scorch in Brazil, associated with Xylella fastidiosa subsp. pauca; Phytopathology Mediterranean, New York, v.55, p.130-135, 2016.

3. Dalbó, M.A.; Bruna, E.D.; Nodari, R.O.; Saifert, L. Plum selections with total resistance to leaf scald (Xylella fastidiosa). Acta Horticulturae, Lovaina, v.1127, p.61-64, 2016.

4. Dalbó, M.A.; Bruna, E.D.; Souza, A.L.K. SCS 438 Zafira - a new plum cultivar resistant to leaf scald (Xylella fastidiosa). Crop Breeding and Applied Biotechnology, Viçosa, v.18, n.2, p.229-233, Apr. 2018.

5. Ducroquet, J-P. H. J.; Andrade, E.R.; Hickel, E.R. A escaldadura das folhas da ameixeira em Santa Catarina. Floranópolis: EPAGRI, 2001. (Boletim Técnico, 118).
6. Eidam, T.; Pavanello, A.P. Ameixeira no Brasil. Revista Brasileira de Fruticultura, Jaboticabal, v.34, n.1, p.12-20, Mar. 2012.

7. Fioravanço, J.C.; Alves, S.A.M.; Cardoso, A.G.F. Avaliação Agronômica da Ameixeira 'América Tardia', em Vacaria/RS. Pelotas: Embrapa Clima Temperado, 2015. 9p. (Embrapa Clima Temperado. Circular Técnica, 120).

8. Hopkins, D.L.Y.; Purcell, A.H. Xylella fastidiosa: cause of Pierce's disease of grapevine and other emergent diseases; Plant Disease, Saint Paul, v.86, p.1056-1066, 2002.

9. Jacques, M.A.; Coletta-filho, H.D.; Burbank, L.; Clover, G.; Elansky, S.; Marques, A.A.; Sutton-croft, M.; Takai, Y. G20 MACS Transboundary and emerging pests: Xylella fastidiosa. Plant Pests, Kingdown, v.1, p. $1-31,2019$.

10. Kleina, H.T.; Padua, T.; Jacomino, A.P.; May de Mio L.L. Postharvest quality of plums in response to the occurrence of leaf scald disease. Postharvest Biology and Technology, Amsterdam, v.143, p.102-111, 2018.

11. Leite, R.P.; Nunes, L.M.. Avanços nas pesquisas sobre Xylella fastidiosa do café no Brasil. In: Zambolim, L. (ed.). Produção integrada de café. Viçosa: DFP, 2003. p.87-101.

12. May de Mio, L.L.; Garrido, L.R.; Ueno, B. Doenças de fruteiras de caroço. In.: Monteiro, L. B.; May De Mio, L.L.; Serrat, B.M.; Motta, A.C.V.; Cuquel, F.L. (ed.). Fruteiras de caroço: uma visão ecológica. Curitiba: UFPR, 2004. cap.10, p.169-221.

13. Mckinney, H.H. Influence of soil, temperature and moisture on infection of wheat seedlings by Helminthosporium sativum. Journal of Agricultural Research, Washington, v.26, p.195-217, 1923.

14. Minsavage, G.V.; Thompson, C.M.; Hopkins, D.L.; Leite, R.M.V.B.C.; Stall, R.E. Development of a polymerase chain reaction protocol for detection of Xylella fastidiosa in plant tissue. Phytopathology, Saint Paul, v.84, p.456-461. 1994.

15. Palacio Bielsa, A. Xylella fastidiosa, un problema global: enfermedades que causa, diagnóstico y control. Zaragosa: Editora Cita, 2017.

16. Redak, R.A.; Purcell, A.H.; Lopes, J.R.S.; Blua, M.J.; Mizel III, R.F.Y.; Andersen, P.C. The biology of xylem fluid-feeding insect vectors of Xylella fastidiosa and their relation to disease epidemiology; Annual Review of Entomology, Palo Alto, v.49, p.243-270, 2004.

17. Ringenberg, R.; Lopes, J.R.S.; Müller, C.; Azevedo-filho, W.S.D.; Paranhos, B.A.J.; Botton, M. Survey of potential sharpshooter and spittlebug vectors of Xylella fastidiosa to grapevines at the São Francisco River Valley, Brazil. Revista Brasileira de Entomologia, Curitiba, v.58, n.2, p.212-218, 2014.

18. Schneider, N.A.; De Azevedo Filho, W.S. Epidemiologia da escaldadura das folhas da ameixeira. Caderno de Pesquisa, Santa Cruz do Sul, v.26, n.2, p.25-40, 2014

19. Silva, M.R.L.; Meneguim, A.M.; Paião, F.G.; Meneguim, L.; Canteri, M.G.; Leite Jr, R.P. Infectividade natural por Xylella fastidiosa Wells et al. de Cicadelíneos (Hemiptera: Cicadellidae) de lavouras cafeeiras do Paraná. Neotropical Entomology, Londrina, v.36, p.274-281, 2007. 